\title{
Solubility of C-O-H mixtures in natural melts: new experimental data and application range of recent models
}

\author{
Roman Botcharnikov, Marcus Freise, Francois Holtz and Harald Behrens \\ Institut für Mineralogie, Uni Hannover, Germany
}

\begin{abstract}
The effect of pressure, temperature, and melt composition on $\mathrm{CO}_{2}$ and $\mathrm{H}_{2} \mathrm{O}$ solubilities in aluminosilicate melts, coexisting with $\mathrm{CO}_{2}-\mathrm{H}_{2} \mathrm{O}$ fluids, is discussed on the basis of previously published and new experimental data. The datasets have been chosen so that $\mathrm{CO}_{2}$ and $\mathrm{H}_{2} \mathrm{O}$ are the main fluid components and the conclusions are only valid for relatively oxidizing conditions. The most important parameters controlling the solubilities of $\mathrm{H}_{2} \mathrm{O}$ and $\mathrm{CO}_{2}$ are pressure and composition of melt and fluid. On the other hand, the effect of temperature on volatile solubilities is relatively small. At pressures up to $200 \mathrm{MPa}$, intermediate compositions such as dacite, in which both molecular $\mathrm{CO}_{2}$ and carbonate species can be dissolved, show higher volatile solubilities than rhyolite and basalt. At higher pressures $(0.5$ to $1 \mathrm{GPa})$, basaltic melts can incorporate higher amounts of carbon dioxide (by a factor of 2 to 3 ) than rhyolitic and dacitic melts. Henrian behavior is observed only for $\mathrm{CO}_{2}$ solubility in equilibrium with $\mathrm{H}_{2} \mathrm{O}-\mathrm{CO}_{2}$ fluids at pressures $<100 \mathrm{MPa}$, whereas at higher pressures $\mathrm{CO}_{2}$ solubility varies nonlinearly with $\mathrm{CO}_{2}$ fugacity. The positive deviation from linearity with almost constant $\mathrm{CO}_{2}$ solubility at low water activity indicates that dissolved water strongly enhances the solubility of $\mathrm{CO}_{2}$. Water always shows non-Henrian solubility behavior because of its complex dissolution mechanism (incorporation of $\mathrm{OH}$-groups and $\mathrm{H}_{2} \mathrm{O}$ molecules in the melt). The model of Newman and Lowenstern (2002), in which ideal mixing between volatiles in both fluid and melt phases is assumed, reproduces adequately the experimental data for rhyolitic and basaltic compositions at pressures below $200 \mathrm{MPa}$ but shows noticeable disagreement at higher pressures, especially for basalt. The empirical model of Liu et al. (2004) is applicable to rhyolitic melts in a wide range of pressure (0-500 MPa) and temperature (700$1200^{\circ} \mathrm{C}$ ) but cannot be used for other melt compositions. The thermodynamic approach of Papale (1999) allows to calculate the effect of melt composition on volatile solubilities but needs an update to account for more recent experimental data. A disadvantage of this model is that it is not available as a program code. The review indicates a crucial need of new experimental data for scarcely investigated field of pressures and fluid compositions and new models describing evident non-ideality of $\mathrm{H}-\mathrm{C}-\mathrm{O}$ fluid solubility in silicate melts at high pressures.
\end{abstract}

Key words $\mathrm{CO}_{2}-\mathrm{H}_{2} \mathrm{O}$ - solubility - mixed fluid silicate melt - experimental data

Mailing address: Dr. Roman Botcharnikov, Institut für Mineralogie, Uni Hannover, Callinstr. 3, D-30167 Hannover, Germany; e-mail: R.Botcharnikov@mineralogie.unihannover.de

\section{Introduction}

The knowledge of the distribution of volatile species between silicate melts and gases (or fluids) is crucial to understand degassing processes in magmatic systems. Although natural fluids are complex multicomponent phases and may contain several mol\% $\mathrm{SO}_{2}, \mathrm{H}_{2} \mathrm{~S}, \mathrm{HCl}$, $\mathrm{HF}$ and others, $\mathrm{CO}_{2}$ and $\mathrm{H}_{2} \mathrm{O}$ are commonly the major fluid species exsolving from degassing magmatic melts and the system $\mathrm{C}-\mathrm{O}-\mathrm{H}$ is often 
taken as an analogue for natural mixed fluids. However, even in this simplified system, the solubilities of volatile components in melts remain difficult to predict for natural aluminosilicate melts and controversial datasets can be found in the literature. Apart from experimental or analytical problems, two main reasons explain the difficulty to elaborate a general model from the available experimental database: 1) the relative abundance of molecular species (e.g., $\mathrm{CO}, \mathrm{CO}_{2}, \mathrm{H}_{2} \mathrm{O}, \mathrm{CH}_{4}, \mathrm{H}_{2}$ ) in the fluids and their fugacities depend upon pressure, temperature and oxygen fugacity, which is notoriously difficult to control in high pressure and high temperature experiments; 2) the solubility mechanisms of volatiles in silicate melts depend on bulk composition of the melt. For example, carbon is mainly dissolved as molecular $\mathrm{CO}_{2}$ in rhyolites but as carbonate in basalts, and both species are present in intermediate systems (e.g., Holloway and Blank, 1994).

In this study we use the available experimental datasets and new results, presented here, to work out the possible effects of bulk compositions (rhyolite to basalt), pressure and temperature on the solubility of $\mathrm{C}-\mathrm{O}-\mathrm{H}$ species in common natural silicate melts. Thereby, we consider only data from studies in which $\mathrm{CO}_{2}$ and $\mathrm{H}_{2} \mathrm{O}$ have been the dominant species in the coexisting fluid phase. Thus, the discussion is limited to $\mathrm{fO}_{2}$ conditions varying from oxidizing to moderately reducing. For example, at 1 $\mathrm{GPa}, 1400^{\circ} \mathrm{C}, \mathrm{CO}_{2}$ should be the dominant carbon species down to a $\log f_{2}$ of delta NNO-1 (Holloway and Blank, 1994).

Based on pioneering studies on water and $\mathrm{CO}_{2}$ solubilities in silicate melts (e.g., Burnham and Davis 1971, 1974; Holloway, 1987; Stolper, 1982; Silver and Stolper, 1985; Fogel and Rutherford, 1990; Blank et al., 1993; Dixon et al., 1995), models for predicting $\mathrm{CO}_{2}$ and $\mathrm{H}_{2} \mathrm{O}$ solubilities and equilibrium fluid compositions have been elaborated by Holloway and Blank (1994), Dixon (1997), Papale (1999) and Newman and Lowenstern (2002). The merit of the VolatileCalc model proposed by Newman and Lowenstern (2002) is that the software is directly available and that it can be used easily to model magmatic processes in basaltic and rhyolitic systems. The authors recommend using the model up to $500 \mathrm{MPa}$ (but not above) and examples of applications are given by Lowenstern (2000, 2001). In addition, an empirical model was proposed by Liu et al. (2004) to predict $\mathrm{CO}_{2}$ and $\mathrm{H}_{2} \mathrm{O}$ solubilities in rhyolitic melts. Applicability and limitations of the more recent models ( $\mathrm{Pa}-$ pale, 1999; Newman and Lowenstern, 2002; Liu et al., 2004) are discussed in the light of new experimental data.

\section{Generalities}

The solubility of volatiles in melts in equilibrium with a C-O-H-bearing fluid is commonly represented as shown in fig. 1 for rhyolitic melts. The $X$ - and $Y$-axes in fig. 1 correspond to the amount of dissolved $\mathrm{O}-\mathrm{H}$ species (expressed as wt $\% \mathrm{H}_{2} \mathrm{O}$ ) and of dissolved $\mathrm{C}-\mathrm{O}$ species (expressed as wt $\% \mathrm{CO}_{2}$ ) in the silicate melt, respectively. The thick curves in fig. 1 represent the maximum amount of $\mathrm{H}_{2} \mathrm{O}$ and $\mathrm{CO}_{2}$ which can be dissolved concomitantly in melts coexisting with $\mathrm{C}-\mathrm{O}-\mathrm{H}$-bearing fluids. The intersections of the solubility curves with the $X$ - and $Y$-axes of fig. 1 correspond to the solubility of pure $\mathrm{H}_{2} \mathrm{O}$ or $\mathrm{CO}_{2}$, respectively. The composition of the fluid coexisting with the melt is given by the thin lines (for fixed mole fraction of water, $\left.X_{\mathrm{H}_{2} \mathrm{O}}^{f}\right)$. At a given pressure $(P)$ and temperature $(T)$, melts in equilibrium with water-rich fluids contain high water amounts and can only incorporate little $\mathrm{CO}_{2}$ (the water activity in such systems is high) whereas melts equilibrated with $\mathrm{CO}_{2}$-rich fluids contain less water and can incorporate higher $\mathrm{CO}_{2}$ amounts (the water activity is low).

The thick curves in fig. 1 show that volatile solubility is strongly dependent on pressure. The nonlinear shape, especially marked at high pressure $(500 \mathrm{MPa})$ is the result of non-ideal solubility behavior of mixed $\mathrm{C}-\mathrm{O}-\mathrm{H}$ fluids in the silicate melt. In pioneering experiments performed at high pressure (up to $2 \mathrm{GPa}$ ), the addition of small amounts of water to a $\mathrm{CO}_{2}$ bearing fluid was found to increase the solubility of $\mathrm{CO}_{2}$ (Mysen et al., 1976). This cannot be observed in rhyolite melts up to $500 \mathrm{MPa}$ (fig. 1) but does not necessarily disagree with the high pressure studies in which the amounts of 


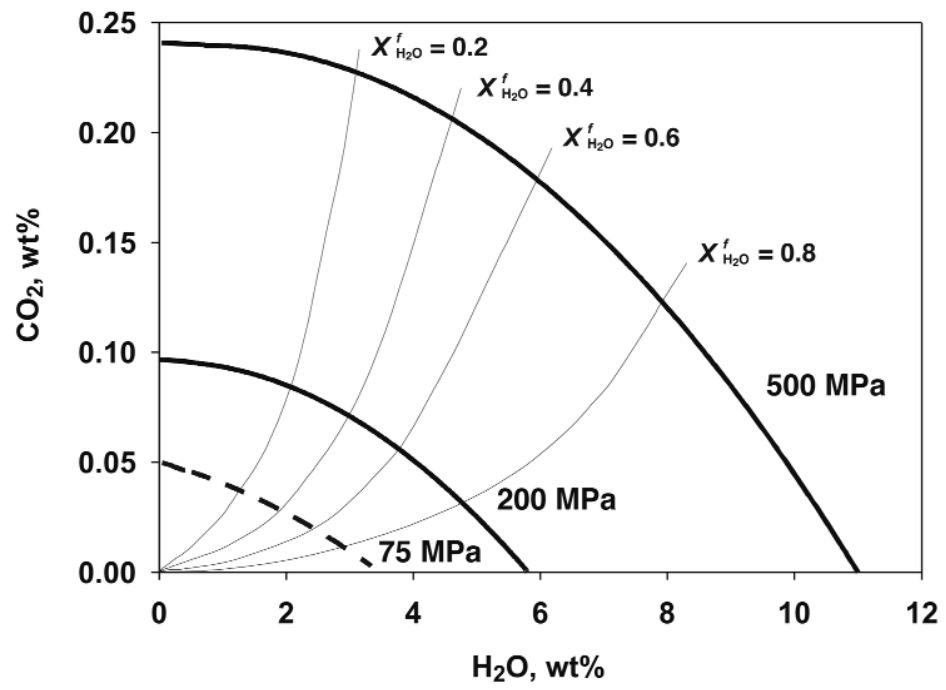

Fig. 1. Typical diagram illustrating solubility of volatiles in aluminosilicate melts in equilibrium with $\mathrm{C}-\mathrm{O}-\mathrm{H}$ fluids. The curves are based on the experimental datasets obtained by Blank et al. (1993) at $T=850^{\circ} \mathrm{C}$ and $P=75$ $\mathrm{MPa}$ and Tamic et al. (2001) at $T=1100^{\circ} \mathrm{C}$ and 200 and $500 \mathrm{MPa}$ for rhyolitic melts.

dissolved C-O-H species are much higher (see discussion in Holloway and Blank, 1994). It must be noted also that water has a similar positive effect on solubility of noble gases in rhyolitic and basaltic melts as found experimentally by Paonita et al. (2000) and modeled by Nuccio and Paonita (2000). The authors showed that the solubility of noble gases in silicate melts at 100 to $200 \mathrm{MPa}$ and 1130 to $1160^{\circ} \mathrm{C}$ increases with $\mathrm{H}_{2} \mathrm{O}$ content of the melt and becomes almost constant when water concentration is higher than $3 \mathrm{wt} \%$. The qualitative explanation of the noble gas solubility enhancement has been that new sites for noble gas atoms are created due to depolymerization of the silicate melt structure by dissolved $\mathrm{H}_{2} \mathrm{O}$. It can be expected that a reactive molecule such as $\mathrm{CO}_{2}$ shows an even more pronounced dependence on dissolved water in the melt. However, the discussion of incorporation mechanisms of $\mathrm{H}_{2} \mathrm{O}$ and $\mathrm{CO}_{2}$ in silicate melt is beyond the scope of this paper which is restricted mainly to a review of the existing experimental and modeled data on the solubility of $\mathrm{H}_{2} \mathrm{O}$ and $\mathrm{CO}_{2}$ in silicate melts.
Examples for using diagrams of the same type than fig. 1 for various melt compositions are given by Holloway and Blank (1994) and Dixon et al. (1995). The curves in fig. 1 can be used to determine the $P-T$ conditions at which magma starts to degas (provided that the amount of dissolved C-O-H species is known), to determine the partitioning of $\mathrm{CO}_{2}$ and $\mathrm{H}_{2} \mathrm{O}$ between coexisting melts and fluids, and therefore the evolution of fluid compositions during degassing processes in open or closed systems (e.g., Dixon and Stolper, 1995). The recent model of Newman and Lowenstern (2002) allows us to calculate directly the evolution trends for volatile concentrations in melt and fluid phases. Experimental datasets on volatile partitioning between fluids and melts at high $T$ and high $P$ are scarce. Identification and quantification of equilibrium volatile species in fluids from quenched products are difficult. Hence, most studies have been concentrated on the determination of the solubility curves only (the analysis of volatile concentrations in quenched glasses is less problematic). Thus, we focused this review on the effects of $P, T$, and 
melt composition on the solubility of $\mathrm{C}-\mathrm{O}-\mathrm{H}$ species in silicate melts (thick lines in fig. 1).

\section{Solubilities of $\mathrm{H}_{2} \mathrm{O}$ and $\mathrm{CO}_{2}$ as a function of temperature}

Experimental datasets on solubilities of both carbon dioxide and water in rhyolitic silicate melts equilibrated with $\mathrm{C}-\mathrm{H}-\mathrm{O}$ fluids are available from the studies of Blank et al. (1993) and of Tamic et al. (2001). Blank et al. (1993) performed experiments at $850^{\circ} \mathrm{C}$ and $75 \mathrm{MPa}$ and Tamic et al. (2001) at higher pressures of 200 and $500 \mathrm{MPa}$ and temperatures of $1100^{\circ} \mathrm{C}$ and $800^{\circ} \mathrm{C}$ (figs. 1 and 2). In both studies, the $\mathrm{CO}_{2}$ concentration was determined by infrared spectroscopy using the absorption coefficient of $1066 \mathrm{l} \cdot \mathrm{mol}^{-1} \cdot \mathrm{cm}^{-1}$ from Blank (1993) for the absorption band at $2348 \mathrm{~cm}^{-1}$. Recently, Behrens et al. (2004a) proposed a new absorption coefficient $\left(1214 \mathrm{l} \cdot \mathrm{mol}^{-1} \cdot \mathrm{cm}^{-1}\right)$ for the molecular
$\mathrm{CO}_{2}$ band in hydrous rhyolitic glasses. Thus, the reported data of Tamic et al. (2001) and Blank et al. (1993) have been corrected and are slightly lower than previously published by $12 \%$ relative. The best fits of the corrected experimental data are presented in fig. 2 .

At low pressure $(75 \mathrm{MPa})$, the $\mathrm{CO}_{2}$ content varies almost linearly with $\mathrm{H}_{2} \mathrm{O}$ content of the melt. With increasing pressure, deviation from linearity becomes more and more pronounced. Temperature has no significant effect on the $\mathrm{H}_{2} \mathrm{O}-\mathrm{CO}_{2}$ solubility curve at $200 \mathrm{MPa}$ but shifts the curve towards higher values at $500 \mathrm{MPa}$, at least in water-rich systems.

To test the ability of the VolatileCalc model of Newmann and Lowenstern (2002; further in the text referred to as $\mathrm{N} \& \mathrm{~L}$ ) to reproduce the experimental data, the calculated $\mathrm{H}_{2} \mathrm{O}$ and $\mathrm{CO}_{2}$ concentrations in the rhyolitic melts are shown in fig. 2 as gray lines. The calculations have been carried out for the same temperatures and pressures as reported for the experimental data.

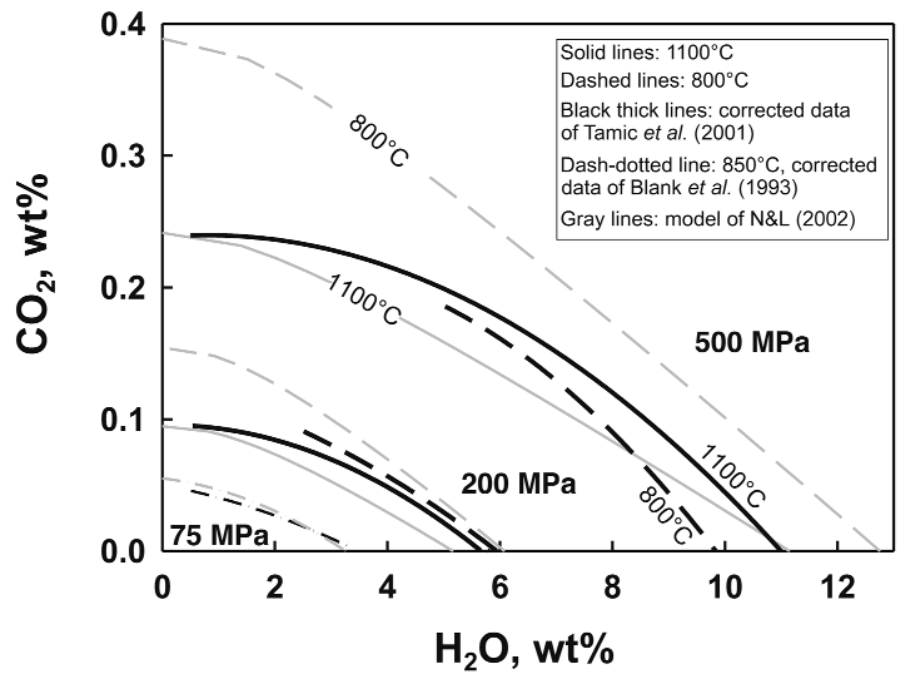

Fig. 2. Temperature dependence of $\mathrm{H}_{2} \mathrm{O}$ and $\mathrm{CO}_{2}$ solubility in rhyolitic melt at 200 and $500 \mathrm{MPa}$ after Tamic et al. (2001). The data of Blank et al. (1993) are shown for comparison. All data have been corrected using the IR absorption coefficient for molecular $\mathrm{CO}_{2}$ of $1216 \mathrm{l} \cdot \mathrm{mol}^{-1} \cdot \mathrm{cm}^{-1}$ after Behrens et al. (2004a). Gray lines are the calculated volatile solubilities by the model of Newman and Lowenstern (2002). Note the opposite temperature effects observed in experimental and modeled solubility curves at $500 \mathrm{MPa}$. The predictions of the empirical model of Liu et al. (2004) coincide with the fits of experimental data and not presented in the diagram (for detail see fig. 6 in the work of Liu et al., 2004). 
The model of N\&L always predicts a negative effect of temperature on volatile solubilities at pressures 200 and $500 \mathrm{MPa}$ and this effect increases with pressure. This trend is in agreement with the experimental data at $200 \mathrm{MPa}$ but it contrasts with the experimental findings for water-rich conditions at $500 \mathrm{MPa}$. Since the model is based on experiments performed with pure $\mathrm{H}_{2} \mathrm{O}$ and $\mathrm{CO}_{2}$ fluid phases (Silver, 1988; Silver et al., 1990; Fogel and Rutherford, 1990), and on the low-pressure data of Blank et al. (1993), it reproduces data for mixed fluids with a good precision only at low pressures (deviations are almost in the range of the error bars). It is noteworthy that at $500 \mathrm{MPa}$, the model of $\mathrm{N} \& \mathrm{~L}$ predicts almost linear solubility curves in the $\mathrm{H}_{2} \mathrm{O}-\mathrm{CO}_{2}$ solubility field and does not reproduce the non-linear solubility behavior of $\mathrm{CO}_{2}$ and $\mathrm{H}_{2} \mathrm{O}$ in the C-H-O-rhyolite system. This is due to the assumption of an ideal behavior of volatiles and independence of $\mathrm{H}_{2} \mathrm{O}$ solubility on $\mathrm{CO}_{2}$ concentration in the melt and vice versa in the N\&L's model. The empirical model of Liu et al. (2004) gives a much better prediction of solubility trends, especially at high $P$. The calculated solubility curves coincide with the fitted experimental data (fig. 2).

A rough estimation of the temperature dependence of $\mathrm{H}_{2} \mathrm{O}-\mathrm{CO}_{2}$ solubility in basaltic melts can be derived comparing the results of Dixon et al. (1995) and Jendrzejewski et al. (1997) obtained at 1200 and $1300^{\circ} \mathrm{C}$, respectively. Since solubility of volatiles is a strong function of pressure, it is possible to compare only a few experimental data obtained at 50 $\mathrm{MPa}$. In these two studies, different absorption coefficients were used to calculate the amount of dissolved $\mathrm{CO}_{2}$ from the peak height of the mid infrared carbonate band at $1522 \mathrm{~cm}^{-1}$. Applying the same absorption coefficient for both studies $\left(3981 \cdot \mathrm{mol}^{-1} \cdot \mathrm{cm}^{-1}\right.$, Jendrzejewski et al., 1997) and using samples with similar water content ( 0.35 to $\left.0.4 \mathrm{wt} \% \mathrm{H}_{2} \mathrm{O}\right)$, the $\mathrm{CO}_{2}$ solubility is $210 \mathrm{ppm}$ at $1200^{\circ} \mathrm{C}$ (Dixon et al., 1995) and $257 \mathrm{ppm}$ at $1300^{\circ} \mathrm{C}$ (Jendrzejewski et al., 1997). This suggests that temperature may have a small positive effect on $\mathrm{CO}_{2}$ solubility at 50 $\mathrm{MPa}$ in basaltic melts. However, this conclusion is based on data from different laboratories and may be an artifact of different experimental conditions. In contrast, Pan et al. (1991) noted a negative temperature dependence of pure $\mathrm{CO}_{2}$ solubility at higher pressures (1.0 and $1.5 \mathrm{GPa})$. However, the variation of $\mathrm{CO}_{2}$ solubility is small and remains constant within error over a temperature range from 1300 to $1600^{\circ} \mathrm{C}$. It can be noted that, in the pressure range 0.5 to 3.5 $\mathrm{GPa}$, a compilation of all available data for $\mathrm{CO}_{2}$ solubilities in other silicate liquids coexisting with pure $\mathrm{CO}_{2}$ confirms a general negative temperature effect on $\mathrm{CO}_{2}$ solubility in a variety of compositions (Ca-rich leucitite: Thibault and Holloway, 1994; albite: Stolper et al., 1987, melilitite: Brey, 1976; diopside: Rai et al., 1983; Ca-melilitite, Mg-melilitite, phonolite, andesite: Brooker et al., 2001; haplo-phonolite: Morizet et al., 2002).

\section{The effect of melt composition on $\mathrm{H}_{2} \mathrm{O}$ and $\mathrm{CO}_{2}$ volatile solubilities}

It is well known that the solubilities of water and $\mathrm{CO}_{2}$ in silicate melts are strongly dependent on the melt composition. In general, at given $P$ and $T$, the $\mathrm{H}_{2} \mathrm{O}$ solubility increases whereas the $\mathrm{CO}_{2}$ solubility decreases with $\mathrm{SiO}_{2}$ content of the melt (e.g., Blank and Brooker, 1994; Holloway and Blank, 1994; Brooker et al., 2001; King and Holloway, 2002).

To understand the compositional effects of the melt on the solubility of $\mathrm{H}_{2} \mathrm{O}$ and $\mathrm{CO}_{2}$, experimental data obtained at identical pressures have to be compared. Identical temperatures may be not strictly required because of the small temperature dependence of volatile solubilities. Only few experimental datasets for silicate melts of different compositions at same pressure are available in the literature. The pressure range in which comparisons are possible is $75 \mathrm{MPa}$ to 1 $\mathrm{GPa}$. The existing data are mostly restricted to the rhyolitic and basaltic compositions (e.g., Blank et al., 1993; Dixon et al., 1995; Tamic et al., 2001). One study illustrates volatile solubility in icelandite (composition close to andesite, Jakobsson, 1997) at high temperature and pressure. In addition, King and Holloway (2002) studied experimentally the solubility of $\mathrm{H}_{2} \mathrm{O}$ and $\mathrm{CO}_{2}$ in water-poor $\left(<3.5 \mathrm{wt} \% \mathrm{H}_{2} \mathrm{O}\right)$ andesitic melt at $1300^{\circ} \mathrm{C}$ and $1 \mathrm{GPa}$. Recently, Behrens 
et al. (2004b) presented a dataset for dacitic melts investigated at $1250^{\circ} \mathrm{C}$ and 100,200 and $500 \mathrm{MPa}$. In our comparison, we also used new experimental data for basaltic melts obtained at $1150^{\circ} \mathrm{C}, 500 \mathrm{MPa}$ and $1200^{\circ} \mathrm{C}, 200 \mathrm{MPa}$ which are presented in more detail in the Appendix A.

Systematic datasets at same $P$ and $T$ are missing for pressures below $100 \mathrm{MPa}$ and, hence, the direct examination of the difference in $\mathrm{H}_{2} \mathrm{O}$ and $\mathrm{CO}_{2}$ solubility between silicic and mafic melt compositions is difficult. Rough estimations are possible only at $75 \mathrm{MPa}$ based on the data of Blank et al. (1993) for rhyolite at $850^{\circ} \mathrm{C}$ and one sample of Jendrzejewski et al. (1997) for basalt at $1300^{\circ} \mathrm{C}$. The results show that the concentrations of dissolved $\mathrm{CO}_{2}$ are higher in rhyolite than in basalt $(450 \mathrm{ppm}$ for rhyolite, corrected value, and $370 \mathrm{ppm}$ for basalt), neglecting the temperature effect (which should be small at this pressure). The experiments of Dixon et al. (1995), performed at $72 \mathrm{MPa}$ and $1200^{\circ} \mathrm{C}$, also indicate lower sol- ubility of volatiles in basalt (290 ppm $\mathrm{CO}_{2}$, value corrected).

At $100 \mathrm{MPa}$, compositional trends can be extracted from three studies (fig. 3): two for basalt (Pawley et al., 1992; Jendrzejewski et al., 1997) and one for dacite (Behrens et al., 2004b). Note that we present only the data of Pawley et al. (1992) for relatively oxidizing conditions assuming that $\mathrm{CO}_{2}$ and $\mathrm{H}_{2} \mathrm{O}$ are the main fluid species. For low water contents, the data for basaltic melts indicate $\mathrm{CO}_{2}$ solubility in the range 500-650 ppm. The solubility of both $\mathrm{CO}_{2}$ and $\mathrm{H}_{2} \mathrm{O}$ is slightly higher in dacitic melt than in basaltic melt (fig. 3) in the $\mathrm{CO}_{2}$-rich as well as in the $\mathrm{H}_{2} \mathrm{O}$ -rich part of the diagram. For comparison, the modeled solubilities (N\&L) of C-O-H species in rhyolite and basalt (calculated for $\mathrm{SiO}_{2}=49 \mathrm{wt} \%$ ) are shown as gray lines in fig. 3. The model is within the experimental error for basaltic melts but tends to underestimate slightly the volatile solubilities. Assuming that volatile solubilities in rhyolite and dacite do not differ strongly at 100

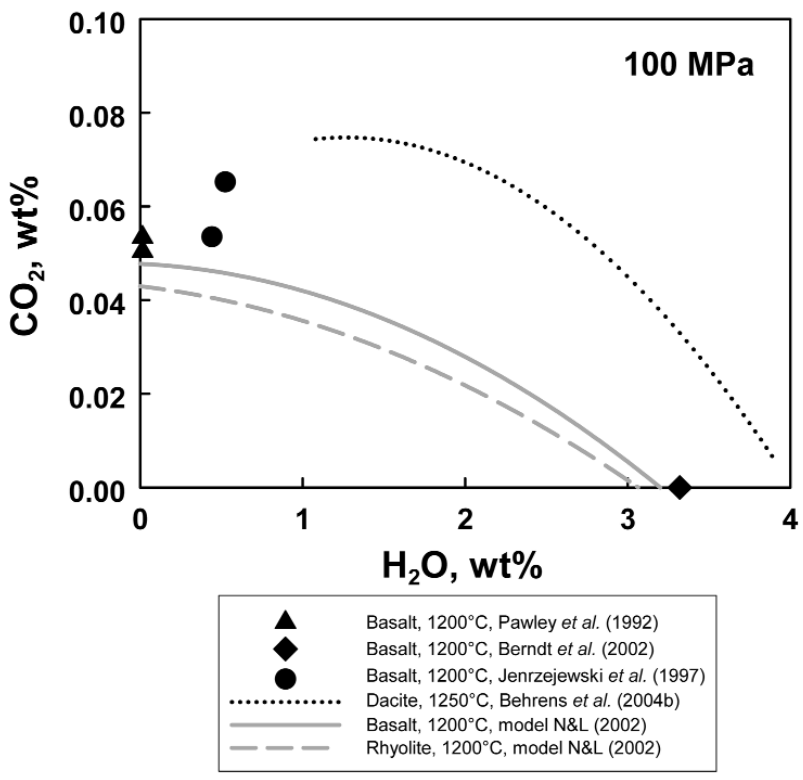

Fig. 3. Solubilities of $\mathrm{H}_{2} \mathrm{O}$ and $\mathrm{CO}_{2}$ in basaltic (dots) and dacitic (dotted line) melts at $100 \mathrm{MPa}$. The dataset for dacitic melt and the experimental procedure is described in detail by Behrens et al. (2004b). Gray lines show modeled solubilities of volatiles in rhyolitic (dashed line) and basaltic (solid line) melt compositions. 


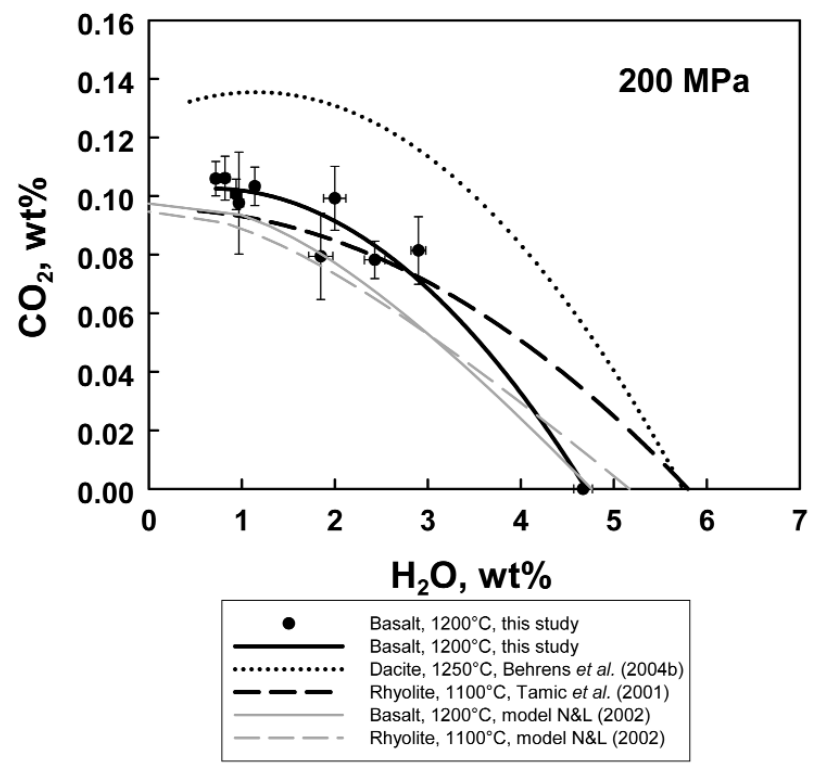

Fig. 4. The effect of silicate melt composition on solubilities of water and carbon dioxide at $200 \mathrm{MPa}$ in the temperature range $1100-1250^{\circ} \mathrm{C}$. The black lines are the best polynomial (2nd order) fits of experimental data.

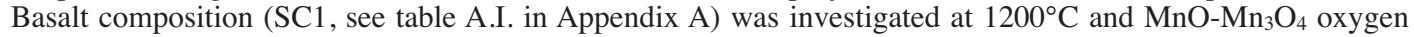
buffer (to vary mole fraction of $\mathrm{H}_{2} \mathrm{O}$ in the fluid phase, $\mathrm{CO}_{2}$ was added as silver oxalate source, $\mathrm{Ag}_{2} \mathrm{C}_{2} \mathrm{O}_{4}$ ). The description of experimental and analytical technique is presented in the Appendix A. Gray lines are modeled solubilities for rhyolite and basalt after Newman and Lowenstern (2002).

$\mathrm{MPa}$ (which is at least the case for pure water solubility), this underestimation is more pronounced for dacite and rhyolite melts.

The available experimental data for different melt compositions at $200 \mathrm{MPa}$ are summarized in fig. 4. Assuming that the temperature effect is low, the solubilities of $\mathrm{H}_{2} \mathrm{O}$ and $\mathrm{CO}_{2}$ in rhyolite and basalt do not differ significantly, except for water-rich compositions. At high water activities, water solubility is known to be higher in rhyolitic than in basaltic melts. The volatile solubility curves, calculated with the N\&L model (basaltic system is modeled again for $\mathrm{SiO}_{2}=49 \mathrm{wt} \%$ ), predict lower values than the experimental data. It should be noted that dacitic melt shows a higher ability to dissolve $\mathrm{CO}_{2}$ and $\mathrm{H}_{2} \mathrm{O}$ when compared to basalt and higher ability to dissolve $\mathrm{CO}_{2}$ when compared to rhyolite. This difference may be related to the presence of both molecular $\mathrm{CO}_{2}$ and carbonate species in dacitic melt.
At $500 \mathrm{MPa}$ total pressure, a similar $\mathrm{CO}_{2}$ solubility gap between rhyolite and dacite can be observed (fig. 5). However, in contrast to lower pressures, basaltic melts have a much higher capacity to dissolve C-O species compared to rhyolitic and dacitic melts (figs. 3, 4 and 5). The increase in $\mathrm{CO}_{2}$ concentration in basaltic melts is very pronounced with the first addition of $\mathrm{CO}_{2}$ to the fluid. With a further increase in the mole fraction of $\mathrm{CO}_{2}$ in the fluid $\left(X_{\mathrm{CO}_{2}}^{f}\right)$, the $\mathrm{CO}_{2}$ solubility remains almost constant. The strong deviation from an ideal behavior in basalt melt suggests that water dissolved in basaltic melt may influence the solubility mechanism of $\mathrm{CO}_{2}$ and stabilize carbonate groups (e.g., King and Holloway, 2002). The $\mathrm{CO}_{2}$ solubility in basalt melts for high $X_{\mathrm{CO}_{2}}$ shown in fig. 5 is approximately two times higher than values extrapolated from data of Pan et al. (1991). This may be related to the effect of oxygen fugacity influencing the fluid phase composition and particularly the 


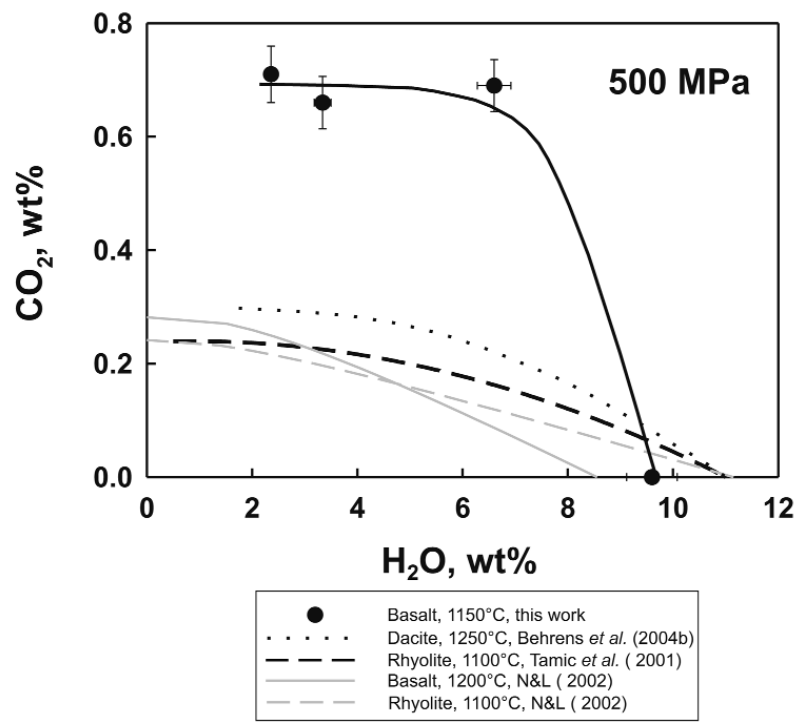

Fig. 5. The solubility of $\mathrm{H}_{2} \mathrm{O}$ and $\mathrm{CO}_{2}$ in melts of different compositions at $500 \mathrm{MPa}$. The experimental strategy used for the basaltic system (OB93-190) and description of the lines are given in Appendix A and fig. 4. Note the significant increase in $\mathrm{CO}_{2}$ solubility in basalt (by a factor of 2 to 3 ) when compared with rhyolitic and dacitic compositions.

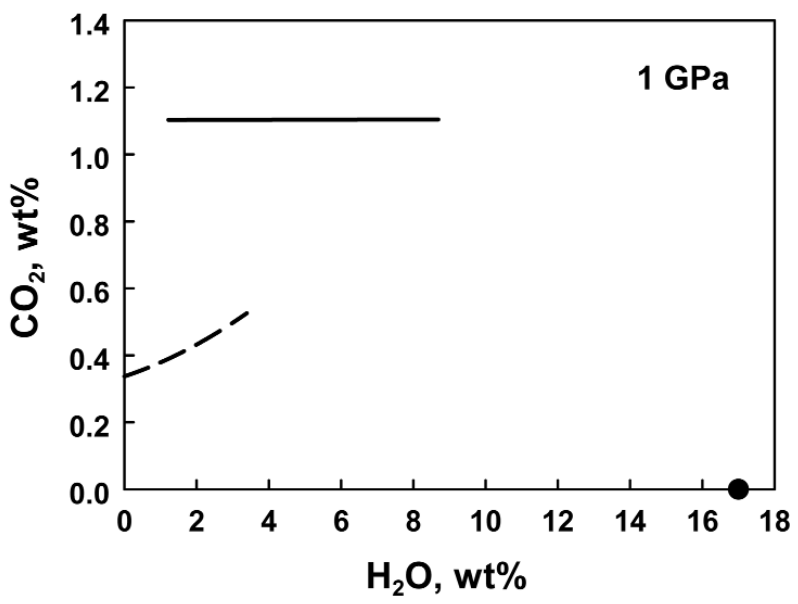

$$
\begin{gathered}
\text { Andesite, } 1300^{\circ} \mathrm{C}, \text { King and Holloway (2002) } \\
\text { Icelandite, } 1400^{\circ} \mathrm{C} \text {, Jakobsson (1997) } \\
\text { Estimated pure } \mathrm{H}_{2} \mathrm{O} \text { solubility in andesite }
\end{gathered}
$$

Fig. 6. Available experimental data on $\mathrm{H}_{2} \mathrm{O}-\mathrm{CO}_{2}$ solubility at $1 \mathrm{GPa}$ for melt compositions close to andesite. Solid and dashed lines are the best fits of the data points obtained by Jakobsson (1997) at $1400^{\circ} \mathrm{C}$ for icelandite $(54.5$ wt $\% \mathrm{SiO}_{2}$ ) and by King and Holloway $(2002)$ at $1300^{\circ} \mathrm{C}$ for andesite $\left(59-60 \mathrm{wt} \% \mathrm{SiO}_{2}\right)$. Remarkable is that the solubility of $\mathrm{CO}_{2}$ in icelandite at low $X_{\mathrm{H}_{2} \mathrm{O}}^{f}$ is almost independent on $\mathrm{H}_{2} \mathrm{O}$ content of the melt (or on water activity), which is similar to the observed solubility behavior of $\mathrm{CO}_{2}$ in basaltic melt at $500 \mathrm{MPa}$ and $1150^{\circ} \mathrm{C}$ (see fig. 5). 
$\mathrm{CO}_{2} / \mathrm{CO}$ ratio (e.g., Pawley et al., 1992). The experiments plotted in figs. 4 and 5 were at strongly oxidizing conditions $\left(\log f \mathrm{O}_{2}=\mathrm{NNO}+3\right.$ if $\left.a \mathrm{H}_{2} \mathrm{O}=1.0\right)$ and those of Pan et al. (1991) at more reducing conditions close to NNO oxygen buffer (note however, that Pan et al., 1991, estimated the molar ratio $\mathrm{CO}_{2} /\left(\mathrm{CO}_{2}+\mathrm{CO}\right)$ to be 0.93). Experimental datasets obtained at identical conditions but different $f \mathrm{O}_{2}$ conditions over a wide range of fluid phase composition $\left(X_{\mathrm{H}_{2} \mathrm{O}}\right.$ varying from 0 to 1 ) would help to understand volatile solubility laws in basaltic melts. The calculated volatile solubilities after Newman and Lowenstern (2002) are presented as gray lines in fig 5 . The predictions are closer to the experimental data for rhyolite than for basalt.

Experimental datasets for andesitic melts obtained at $1 \mathrm{GPa}$ and $1400^{\circ} \mathrm{C}$ (Jakobsson, 1997; icelandite) and $1300^{\circ} \mathrm{C}$ (King and Holloway, 2002) are plotted in fig. 6 . Despite the fact that the temperatures of the experiments are similar, the solubilities of $\mathrm{H}_{2} \mathrm{O}$ and $\mathrm{CO}_{2}$ are found to be much higher in icelandite than in andesite. King and Holloway (2002) attributed this difference to the amount of non-bridging oxygens in both melts, emphasizing that icelandite with 54.5 $\mathrm{wt} \% \mathrm{SiO}_{2}$ has a higher NBO/T content $(0.40)$ than andesite $\left(60 \mathrm{wt} \% \mathrm{SiO}_{2}\right)$ with a NBO/T of 0.30 . It is also interesting to note that the solubility of $\mathrm{CO}_{2}$ in icelandite at $1 \mathrm{GPa}$ is approximately constant over a wide range of $\mathrm{H}_{2} \mathrm{O}$ content of the melt (at high $X_{\mathrm{CO}_{2}}^{f}$ ), as was observed for basaltic melt at $0.5 \mathrm{GPa}$ (see fig. 5).

\section{Pressure effect on $\mathrm{H}_{2} \mathrm{O}$ and $\mathrm{CO}_{2}$ volatile solubilities}

The pressure effect on $\mathrm{H}_{2} \mathrm{O}-\mathrm{CO}_{2}$ solubilities in rhyolite, dacite and basalt melts can be estimated from the comparison of datasets shown on figs. 3-6. In general, pressure has a large positive effect on both $\mathrm{H}_{2} \mathrm{O}$ and $\mathrm{CO}_{2}$ solubility. In detail, the dependence of $\mathrm{CO}_{2}$ solubility on $P$ is more pronounced in basalt (containing carbonates) than in dacite (containing molecular $\mathrm{CO}_{2}$ and carbonates) and in rhyolite (containing only molecular $\mathrm{CO}_{2}$ ). This is consistent with higher reaction volumes when $\mathrm{CO}_{2}$ is dissolved in molecular form compared to its dissolution as carbonate in silicate melts (Holloway and Blank, 1994; Behrens et al., 2004b).

\section{Limitations for using $\mathrm{CO}_{2}-\mathrm{H}_{2} \mathrm{O}$ solubility models}

The comparison between calculated $\mathrm{H}_{2} \mathrm{O}$ $\mathrm{CO}_{2}$ solubilities using the model of $\mathrm{N} \& \mathrm{~L}$ and experimental results (fluids containing mainly $\mathrm{CO}_{2}$ and $\mathrm{H}_{2} \mathrm{O}$ ) shows that the model predicts solubilities within $10 \%$ relative at low pressure (at least up to $200 \mathrm{MPa}$ ). However, at higher pressure, the error of the model can be more than $20 \%$, especially at low temperatures. Furthermore, the temperature effect predicted for rhyolitic melts at $500 \mathrm{MPa}$ is not consistent with the experimental data (fig. 2). In addition, the model does not reproduce the data for basaltic melt at $500 \mathrm{MPa}$. Although experimental data are missing to test the model at pressures between 200 and $500 \mathrm{MPa}$, we suppose that the deviation of calculated data from realistic values increases with pressure. The experimental datasets obtained at $500 \mathrm{MPa}$ and above show increasing non-ideal solubility behavior of C-O$\mathrm{H}$ species with increasing pressure (illustrated by the pronounced curvature of the solubility curves, figs. 5 and 6). The change in shape of the solubility curves with pressure is not reproduced in the model of N\&L. This is a further indication that the ideal-mixing model of $\mathrm{N} \& \mathrm{~L}$ is difficult to apply at pressures above $200 \mathrm{MPa}$.

It can be noted that the model of Papale (1999) is better able to reproduce the experimental data at $500 \mathrm{MPa}$ and above, at least for rhyolitic melts (e.g., see fig. 6 in Tamic et al., 2001). This can be attributed to the fact that the model does not assume ideal mixing in the fluid and melt phases but considers interaction between components. Furthermore, using the recently published experimental data, the thermodynamic approach used by Papale (1999) can be improved to predict accurately $\mathrm{C}-\mathrm{O}-\mathrm{H}$ volatile solubilities in silicate melts. In particular, there is a crucial need for solubility data above $200 \mathrm{MPa}$ for intermediate and mafic melt compositions to calibrate the model of Papale (1999). However, a disadvantage of this model is that it is not available as a program code. 


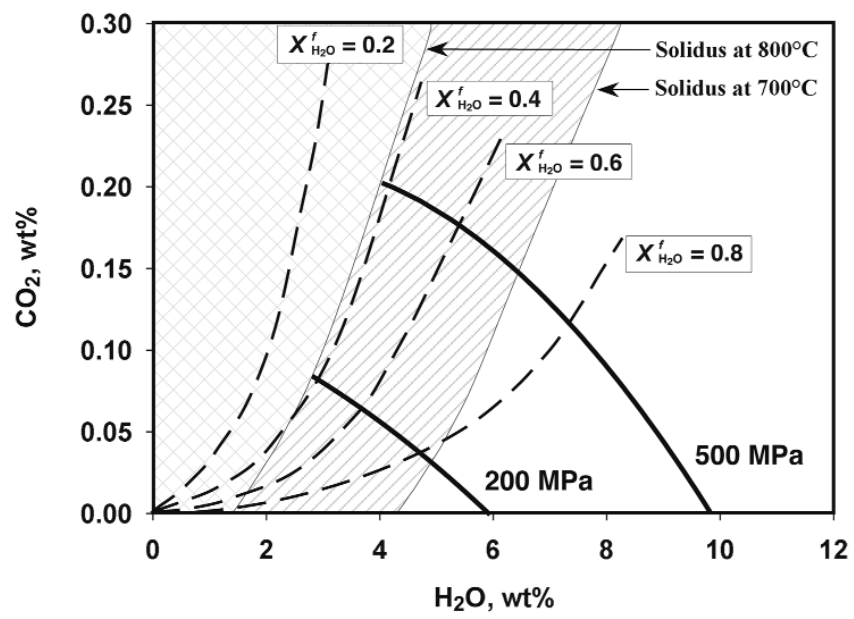

Fig. 7. Limitations for application of solubility models imposed by properties of rhyolitic systems. The curves of $\mathrm{H}_{2} \mathrm{O}-\mathrm{CO}_{2}$ solubility (thick solid lines) are from Tamic et al. (2001) obtained at $800^{\circ} \mathrm{C}$. The hatched area represents the subsolidus region of the eutectic composition in $\mathrm{Ab}-\mathrm{Or}-\mathrm{Qz}$ system at $800^{\circ} \mathrm{C}$. In this field, water activity is too low for melts to be stable $\left(100 \%\right.$ crystallization). The solidus as a function of $P$ and $X_{\mathrm{H}_{2} \mathrm{O}}^{f}$ at $800^{\circ} \mathrm{C}$ has been drawn based on the data of Johannes and Holtz (1996). The area marked by the gray parallel lines and hatched area show the subsolidus field at $700^{\circ} \mathrm{C}$.

\section{Limits for applications of the models}

Recent studies have applied $\mathrm{H}_{2} \mathrm{O}-\mathrm{CO}_{2}$ solubility models to discuss the role of volatiles in the evolution of physical and chemical properties of ascending and crystallizing magmas. For instance, model solubility plots for $\mathrm{H}_{2} \mathrm{O}$ $\mathrm{CO}_{2}$-rhyolitic melt system at $675^{\circ} \mathrm{C}$ and different pressures are shown and discussed by Lowenstern (2000: fig. 2; and 2001: fig. 3). However, the use of such models requires a careful definition of the prevailing conditions and, in particular, kinetic aspects of cooling or decompression in silicic systems. It is well known that solidus temperatures in aluminosilicate systems depend upon water activity. At $800^{\circ} \mathrm{C}, 200 \mathrm{MPa}$ and equilibrium conditions, rhyolitic melts with compositions close to the thermal minimum in the ternary system Qz$\mathrm{Ab}$-Or crystallize if the mole fraction of water in the fluid phase $\left(X_{\mathrm{H}_{2} \mathrm{O}}^{f}\right)$ is below 0.4. This also explains why the data of Tamic et al. (2001) obtained at $800^{\circ} \mathrm{C}$ are restricted to the water-rich part of the diagram in fig. 2. Figure 7 shows the fields in which rhyolitic melts can be stable at given temperatures of 800 and $700^{\circ} \mathrm{C}$. This diagram demonstrates clearly that the discussion of $\mathrm{CO}_{2}$ and $\mathrm{H}_{2} \mathrm{O}$ solubilities in rhyolitic melt at $675^{\circ} \mathrm{C}$ in the range $100-400 \mathrm{MPa}$ (as done by Lowenstern, 2000, 2001) has no physical meaning because at those conditions rhyolitic melts exist only in a very small field of the diagram $\left(P>200 \mathrm{MPa} ; X_{\mathrm{H}_{2} \mathrm{O}}^{f}>0.8\right.$ and melt $\mathrm{H}_{2} \mathrm{O}$ content $>6 \mathrm{wt} \%)$. On the other hand, if cooling or decompression processes are relatively rapid and crystal nucleation and growth are relatively slow, the melt can be metastably preserved and local equilibria can be reached between gas bubbles and small batches of the melt. In this case, the low-temperature solubility models can be applied for such metastable phases but only on the local scale.

\section{Acknowledgements}

We very much appreciated the reviews of $\mathrm{N}$. Metrich and A. Paonita that greatly improved the quality of this paper. P. Papale is acknowledged for editorial work. 
Appendix A. Experimental setup.

\section{A.1. Starting materials and preparation of charges}

In this study, two basaltic compositions were used for experiments on the solubility of $\mathrm{H}-\mathrm{C}-\mathrm{O}$ mixtures in silicate melt. One starting composition (SC1) is a synthetic analogue of a ferrobasalt, which is assumed to be a parental magma of the Skaergaard intrusion (dike $\mathrm{C}$, Brooks and Nielsen, 1978). The starting powder was prepared from mixture of oxides $\left(\mathrm{SiO}_{2}, \mathrm{TiO}_{2}, \mathrm{Al}_{2} \mathrm{O}_{3}, \mathrm{Fe}_{2} \mathrm{O}_{3}, \mathrm{MgO}\right)$ and carbonates $\left(\mathrm{CaCO}_{3}, \mathrm{Na}_{2} \mathrm{CO}_{3}, \mathrm{~K}_{2} \mathrm{CO}_{3}\right)$. The other sample is a natural alkali basalt (OB93-190) from the Mont Crozier on the Courbet Peninsula of the Kerguelen Island. This basalt represents an evolved LIP magma derived from the Kerguelen Plume. A detailed description of the sample OB93190 can be found in Damasceno et al. (2002).

Both starting materials were first ground in a ball mill to $<100 \mu \mathrm{m}$, then loaded in a Pt crucible and fused twice (with grinding in between) for $1 \mathrm{~h}$ at $1600^{\circ} \mathrm{C}$ and $1 \mathrm{~atm}$. The major element compositions of the obtained homogeneous and crystal-free glasses were determined by electron microprobe and are given in table A.I. The powder was sieved to the grain sizes of $<100 \mu \mathrm{m}$ and $100-200 \mu \mathrm{m}$, and two fractions were mixed together in a ratio $\sim 1: 1$ to minimize the free volume between grains when powder is charged into the capsules. Capsules were cleaned in acetone and annealed for $1 \mathrm{~h}$ at $1000^{\circ} \mathrm{C}$ at $1 \mathrm{~atm}$ before use. The capsules were welded shut at one side with an electric arc and filled with glass powder (ca. $20 \mathrm{mg}$ ), $\mathrm{H}_{2} \mathrm{O}$ and/or $\mathrm{Ag}_{2} \mathrm{C}_{2} \mathrm{O}_{4}$. The purity of $\mathrm{Ag}_{2} \mathrm{C}_{2} \mathrm{O}_{4}$ was tested using a gravimetric determination.

The observed weight loss was $90 \%$ of the expected value. Different $\mathrm{H}_{2} \mathrm{O} / \mathrm{CO}_{2}$ ratios were adjusted by varying the amounts of $\mathrm{H}_{2} \mathrm{O}$ and $\mathrm{Ag}_{2} \mathrm{C}_{2} \mathrm{O}_{4}$. The total amount of fluid in the experiments was always higher than the expected fluid-saturation values of the melt. The filled capsules were cooled in liquid nitrogen, welded shut and heated in a drying furnace for $120 \mathrm{~min}$ at $200^{\circ} \mathrm{C}$ to decompose the $\mathrm{Ag}_{2} \mathrm{C}_{2} \mathrm{O}_{4}$ to $\mathrm{Ag}$ and $\mathrm{CO}_{2}$ and to test for possible leakage.

Table A.I. Starting compositions (wt\%).

\begin{tabular}{cccrc}
\hline \hline & \multicolumn{5}{c}{ Microprobe analysis of the starting glasses (a) } \\
\cline { 2 - 5 } & $\mathrm{SC} 1(\mathrm{~b})$ & $\sigma$ & OB93-190 (c) & $\sigma$ \\
\hline $\mathrm{SiO}_{2}$ & 48.34 & 0.29 & 48.84 & 0.54 \\
$\mathrm{TiO}_{2}$ & 2.86 & 0.05 & 2.75 & 0.07 \\
$\mathrm{Al}_{2} \mathrm{O}_{3}$ & 14.61 & 0.13 & 16.14 & 0.26 \\
$\mathrm{FeO}_{\text {tot }}$ & 12.91 & 0.28 & 11.85 & 0.32 \\
$\mathrm{MnO}$ & - & - & 0.17 & 0.05 \\
$\mathrm{MgO}$ & 6.40 & 0.11 & 5.86 & 0.13 \\
$\mathrm{CaO}$ & 10.87 & 0.15 & 9.76 & 0.16 \\
$\mathrm{Na} 2 \mathrm{O}$ & 2.60 & 0.11 & 3.12 & 0.15 \\
$\mathrm{~K}_{2} \mathrm{O}$ & 0.30 & 0.03 & 1.12 & 0.07 \\
$\mathrm{Total}$ & 98.89 & - & 99.60 & - \\
\hline
\end{tabular}

(a) Glass compositions are average values from 10 measurements.

(b) Synthetic analogue of parental liquid of the Skaergaard layered intrusion (Brooks and Nielsen, 1978).

(c) Natural alkali basalt from the Mont Crozier on the Kerguelen Archipelago. 
Table A.II. Experimental results.

\begin{tabular}{cccccc}
\hline \hline Run & $\mathrm{XH}_{2} \mathrm{O}_{\text {fin }}$ & $\mathrm{H}_{2} \mathrm{O}[\mathrm{wt} \%](\mathrm{a})$ & $\sigma$ & $\mathrm{CO}_{2}[\mathrm{ppm}](\mathrm{b})$ & $\sigma$ \\
\hline Ferrobasalt (SC1)/200 $\mathrm{MPa} / 1200^{\circ} \mathrm{C}$ & & & & \\
$\mathrm{B} 17$ & 1.00 & 4.67 & 0.10 & 814 & 115 \\
$\mathrm{~B} 21$ & 0.55 & 2.90 & 0.08 & 782 & 64 \\
$\mathrm{~B} 10$ & 0.44 & 2.43 & 0.11 & 794 & 147 \\
$\mathrm{~B} 19$ & 0.22 & 1.85 & 0.13 & 992 & 109 \\
$\mathrm{~B} 6$ & 0.24 & 2.00 & 0.12 & 1033 & 66 \\
$\mathrm{~B} 9$ & 0.07 & 1.14 & 0.05 & 1006 & 52 \\
$\mathrm{~B} 22$ & 0.06 & 0.94 & 0.06 & 976 & 174 \\
$\mathrm{~B} 7$ & 0.08 & 0.97 & 0.05 & 1061 & 75 \\
$\mathrm{~B} 8$ & 0.05 & 0.82 & 0.05 & 1059 & 59 \\
$\mathrm{~B} 20$ & 0.02 & 0.72 & 0.05 & & \\
Alkali Basalt (OB93-190)/500 MPa/1150 & & & - & - \\
148 & 1.00 & 9.54 & 0.48 & 6530 & 457 \\
149 & 0.62 & 6.47 & 0.32 & 6610 & 462 \\
150 & 0.24 & 3.34 & 0.16 & 7120 & 498 \\
151 & 0.09 & 2.36 & 0.11 & & \\
\hline
\end{tabular}

(a) $\mathrm{H}_{2} \mathrm{O}$ content of the glasses is determined by NIR spectroscopy using the linear absorption coefficient $\varepsilon=$ $=0.56 \mathrm{l} \cdot \mathrm{mol}^{-1} \cdot \mathrm{cm}^{-1}$ for both $\mathrm{OH}^{-}$and $\mathrm{H}_{2} \mathrm{O}$ bands at $4471 \mathrm{~cm}^{-1}$ and $5195 \mathrm{~cm}^{-1}$ after Ohlhorst et al. (2001).

(b) $\mathrm{CO}_{2}$ content of the glasses is determined by MIR spectroscopy using the linear absorption coefficient $\varepsilon=$ $=398 \mathrm{l} \cdot \mathrm{mol}^{-1} \cdot \mathrm{cm}^{-1}$ for the $\mathrm{CO}_{3}^{2-}$ bands at $1522 \mathrm{~cm}^{-1}$ after Jendrzejewski et al. (1997).

\section{A.2. Experimental equipment and run procedure}

All crystallization experiments were conducted in an Internally Heated Pressure Vessel (IHPV) pressurized with Ar as pressure medium. A detailed description of the vessel can be found in Berndt et al. (2002). The temperature in the IHPV was recorded with four unsheathed $S$-type thermocouples with a temperature gradient along the sample of $\pm 3^{\circ} \mathrm{C}$. Total pressure was recorded continuously with a Burster Type 8221 transducer (pressure uncertainty $\pm 1 \mathrm{MPa}$ ). All pressure and temperature data were logged automatically by a LabView(C) Monitoring System. Each experiment consists of a set of 4 capsules which was brought directly to run temperature. The $\mathrm{H}_{2} \mathrm{O} / \mathrm{CO}_{2}$ solubility was investigated under intrinsic conditions of the IHPV $\left(\log f \mathrm{O}_{2} \sim \mathrm{QFM}+4\right)$ at pressures 200 and $500 \mathrm{MPa}$ and temperatures $1200^{\circ} \mathrm{C}$ and $1150^{\circ} \mathrm{C}$ for SC1 and OB93-190 basalts, respectively (see table A.II). The run duration was about $24 \mathrm{~h}$ for the alkali basalt (OB93-190) and 1-1.5 h for the ferrobasalt (SC1). After rapid quench, each capsule was weighted to check for leaks.

\section{A.3. Analytical methods}

A conventional weight-loss method was applied to determine the mole fraction of water in the fluid phase $\left(X_{\mathrm{H}_{2} \mathrm{O}}^{f l}\right): 1$ ) the capsule was weighed; 2$)$ the fluid phase was frozen by placing the capsule in a liquid nitrogen; 3 ) the capsule was pierced with a needle; 4) after warming to room temperature, the capsule was weighed again to determine the mass of $\mathrm{CO}_{2}$ in the fluid and 5) the capsule was 
placed in a drying oven at $110^{\circ} \mathrm{C}$ for $3-5$ min and subsequently weighed to measure the mass of $\mathrm{H}_{2} \mathrm{O}$ lost from the capsule. An entrapment of atmospheric nitrogen in the experimental charge during preparation of the capsules was estimated to be quite low (Tamic et al., 2001) and was not considered in the calculations.

$\mathrm{H}_{2} \mathrm{O}$ and $\mathrm{CO}_{2}$ contents in basaltic glasses were determined using infrared spectroscopy. Volatilebearing glass slabs were ground and polished at both sides to a thickness of 150-200 $\mu \mathrm{m}$ for near-infrared (NIR) and of 30-40 $\mu \mathrm{m}$ for mid-infrared (MIR) spectroscopic measurements. The sample thickness was determined with an accuracy of $\pm 2 \mu \mathrm{m}$ using a digital micrometer. IR absorption spectra were recorded using a Bruker IFS 88 spectrometer equipped with an IR-scope II microscope and an InSb-MCT sandwich detector (local resolution of $100 \times 100 \mu \mathrm{m}$ was adjusted with a slit aperture). Dried air was measured as reference and 100 scans for background and sample measurement were collected. NIR spectra in the range $6000-4000 \mathrm{~cm}^{-1}$ were recorded with a spectral resolution of $4 \mathrm{~cm}^{-1}$, using a tungsten lamp (NIR) and a $\mathrm{CaF}_{2}$ beam splitter. A globar light source and a $\mathrm{KBr}$ beam splitter were used for measuring MIR spectra in the range $4000-1200 \mathrm{~cm}^{-1}$ with a spectral resolution of $2 \mathrm{~cm}^{-1}$.

The $\mathrm{H}_{2} \mathrm{O}$ concentrations in the basaltic glasses were determined using the absorption bands at 5200 $\mathrm{cm}^{-1}$ and $4500 \mathrm{~cm}^{-1}$ for molecular $\mathrm{H}_{2} \mathrm{O}$ and $\mathrm{OH}$-groups, respectively. Absorbances were determined using linear background corrections for each peak. The total $\mathrm{H}_{2} \mathrm{O}$ concentration was calculated using Lambert Beer's Law as described by Ohlhorst et al. (2001). The $\mathrm{CO}_{2}$ concentration of the samples was measured using the band system at $1300-1600 \mathrm{~cm}^{-1}$ due to distorted carbonate groups. The peak height at $1522 \mathrm{~cm}^{-1}$ was determined after subtraction of a reference spectrum of a volatile-free sample normalized to same thickness. Calculation of $\mathrm{CO}_{2}$ concentration follows Jendrzejewski et al. (1997).

The results of analytical measurements are summarized in table A.II and presented in figs. 4 $\left(\mathrm{SC} 1 ; 200 \mathrm{MPa}, 1200^{\circ} \mathrm{C}\right)$ and $5\left(\mathrm{OB} 93-190 ; 500 \mathrm{MPa}, 1150^{\circ} \mathrm{C}\right)$.

\section{REFERENCES}

Behrens, H., N. TAmic and F. Holtz (2004a): Determination of molar absorption coefficient for the IR absorption band of $\mathrm{CO}_{2}$ in rhyolitic glasses, Am. Mineral., 89, 301-306.

Behrens, H., S. Ohlhorst, F. Holtz and M. Champenois (2004b): $\mathrm{CO}_{2}$ solubility in dacitic melts equilibrated with $\mathrm{H}_{2} \mathrm{O}-\mathrm{CO}_{2}$ fluids - Implications for modelling the solubility of $\mathrm{CO}_{2}$ in silicic melts, Geochim. Cosmochim. Acta, 68, 4687-4703.

Berndt, J., C. Liebske, F. Holtz, M. Freise, M. Nowak, D. Ziegenbein, W. HuRKUCK and J. KoePKe (2002): A combined rapid-quench and $\mathrm{H}_{2}$-membrane setup for internally heated pressure vessels: Description and application for water solubility in basaltic melts, Am. Mineral., 87, 1717-1730.

Blank, J.G. (1993) An experimental investigation of the behaviour of carbon dioxide in rhyolitic melt, Ph.D. Dissertation (California Institute of Technology, Pasadena, CA).

Blank, J.G. and R.A. Brooker (1994): Experimental studies of carbon dioxide in silicate melts: solubility, speciation and stable isotope behavior, Rev. Mineral., 30, 157-186.

Blank, J.G., E.M. StolPer and M.R. CARroll (1993): Solubilities of carbon dioxide and water in rhyolitic melt at $850^{\circ} \mathrm{C}$ and 750 bar, Earth Planet. Sci. Lett., 119, 27- 36.

BREY, G. (1976): $\mathrm{CO}_{2}$ solubility and solubility mechanisms in silicate melts at high pressures, Contrib. Mineral. Petrol., 57, 215-221.

Brooker, R.A., S.C. KoHn, J.R. Holloway and P.F. MCMillan (2001): Structural controls on the solubility of $\mathrm{CO}_{2}$ in silicate melts, Part I. Bulk solubility data, Chem. Geol., 174, 225-239.

Brooks, C.K. and T.F.D. NiELSEN (1978): Early stages in the differentiation of the Skaergaard magma as revealed by a closely related suite of dike rocks, Lithos, 11, 1-14.

BurnhaM, C.W. and N.F. DAVIS (1971): The role of $\mathrm{H}_{2} \mathrm{O}$ in silicate melts, I. $P-V-T$ relations in the system NaAl$\mathrm{Si}_{3} \mathrm{O}_{8}-\mathrm{H}_{2} \mathrm{O}$ to 10 kilobar and $1000^{\circ} \mathrm{C}, \mathrm{Am}$. J. Sci., 270, 45-79.

BuRnham, C.W. and N.F. Davis (1974): The role of $\mathrm{H}_{2} \mathrm{O}$ in silicate melts, II. Thermodynamic and phase relations in the system $\mathrm{NaAlSi}_{3} \mathrm{O}_{8}-\mathrm{H}_{2} \mathrm{O}$ to 10 kilobar, $700^{\circ}$ to $1000^{\circ} \mathrm{C}, \mathrm{Am}$. J. Sci., 274, 902-940.

Damasceno, D., J.S. Scoates, D. Weis, F.A. Frey and A. GIRET (2002): Mineral chemistry of mildly alkalic basalts from the 25 Myr Mont Crozier section, Kerguelen Archipelago: constraints on phenocryst crystallisation environments, J. Petrol., 43, 1389-1413.

Dixon, J.E. (1997): Degassing of alkalic basalts, Am. Mineral., 82, 368-378.

Dixon, J.E. and E.M. STOLPER (1995): An experimental study of water and carbon dioxide solubilities in midocean ridge basaltic liquids, Part II. Applications to degassing, J. Petrol., 36, 1633-1646. 
DiXon, J.E., E.M. StolPER and J.R. HollowAy (1995): An experimental study of water and carbon dioxide solubilities in mid-ocean ridge basaltic liquids, Part I. Calibration and solubility models, J. Petrol., 36, 1607-1631.

Fogel, R.A. and M.J. RuthERFORD (1990): The solubility of carbon dioxide in rhyolitic melts: a quantitative FTIR study, Am. Mineral., 75, 1311-1326.

Holloway, J.R. (1987): Igneous fluids, Rev. Mineral., 17, 211-232.

Holloway, J.R. and J.G. BLANK (1994): Application of experimental results to $\mathrm{C}-\mathrm{O}-\mathrm{H}$ species in natural melts, Rev. Mineral., 30, 187-230.

JAKOBSSON, S. (1997): Solubility of water and carbon dioxide in an icelandite at $1400^{\circ} \mathrm{C}$ and 10 kilobar, Contrib. Mineral. Petrol., 127, 129-135.

Jendrzejewski, N., T.W. Trull, F. Pineau and M. Javoy (1997): Carbon solubility in Mid-Ocean Ridge basaltic melt at low pressures (250-1950 bar), Chem. Geol., 138, 81-92.

Johannes, W. and F. Holtz (1996): Petrogenesis and Experimental Petrology of Granitic Rocks (Springer Verlag), pp. 335.

KING, P.L. and J.R. HollowaY (2002): $\mathrm{CO}_{2}$ solubility and speciation in intermediate (andesitic) melts: the role of $\mathrm{H} 2 \mathrm{O}$ and composition, Geochim. Cosmochim. Acta, 66, 1627-1640.

LiU, Y., Y. ZhANG and H. BeHREnS (2004): Solubility of $\mathrm{H}_{2} \mathrm{O}$ in rhyolitic melts at low pressures and a new empirical model to predict $\mathrm{H}_{2} \mathrm{O}$ and $\mathrm{CO}_{2}$ solubility in rhyolitic melts, J. Volcanol. Geotherm. Res., 143, 219-235.

LOWENSTERN, J.B. (2000): A review of the contrasting behavior of two magmatic volatiles: chlorine and carbon dioxide, J. Geochem. Explor., 69-70, 287-290.

LOWENSTERN, J.B. (2001): Carbon dioxide in magmas and implications for hydrothermal systems, Mineral. Deposita, 36, 490-502.

Morizet, Y., R.A. BroOKER and S.C. KoHN (2002): $\mathrm{CO}_{2}$ in haplophonolitic melt: solubility, speciation and carbonate complexation, Geochim. Cosmochim. Acta, 66, 1809-1820.

Mysen, B.O., D.H. Eggler, M.G. Seitz and J.R. HolloWAY (1976): Carbon dioxide solubility in silicate melts and crystals, Part I. Solubility measurements, Am. J. Sci., 276, 455-479.

NEWMAN, S. and J.B. LOWENSTERN (2002): VolatileCalc: a silicate melt $-\mathrm{H}_{2} \mathrm{O}-\mathrm{CO}_{2}$ solution model written in Visual Basic for excel, Comput. Geosc., 28, 597-604.

Nuccio, P.M. and A. PAONITA (2000): Investigation of no- ble gas solubility in $\mathrm{H}_{2} \mathrm{O}-\mathrm{CO}_{2}$ bearing silicate liquids at moderate pressure, II. The Extended Ionic Porosity (EIP) model, Earth Planet. Sci. Lett., 183, 499-512.

OHLHORST, S., H. Behrens and F. Holtz (2001): Compositional dependence of molar absorptivities of near-infrared $\mathrm{OH}-$ and $\mathrm{H}_{2} \mathrm{O}$ bands in rhyolitic to basaltic glasses, Chem. Geol., 174, 5-20.

PAN, V., J.R. Holloway and R.L. Hervig (1991): The pressure and temperature dependence of carbon dioxide solubility in tholeiitic basalt melts, Geochim. Cosmochim. Acta, 55, 1587-1595.

Paonita, A., G. Gigli, D. Gozzi, P.M. Nuccio and R. TrigLIA (2000): Investigation of the He solubility in $\mathrm{H}_{2} \mathrm{O}-\mathrm{CO}_{2}$ bearing silicate liquids at moderate pressure: a new experimental method, Earth Planet. Sci. Lett., 181, 595-604.

PAPAlE, P. (1999): Modeling of the solubility of a two-component $\mathrm{H}_{2} \mathrm{O}+\mathrm{CO}_{2}$ fluid in silicate liquids, Am. Mineral., 84, 477-492.

Pawley, A.R., J.R. Holloway and P.F. McMillan (1992): The effect of oxygen fugacity on the solubility of carbon-oxygen fluids in basaltic melt, Earth Planet Sci. Lett., 110, 213-225.

RaI, C.S., S.K. Sharma, D.W. Meunow, D.W. Matson and C.D. BYERS (1983): Temperature dependence of $\mathrm{CO}_{2}$ solubility in high pressure quenched glass of diopside composition, Geochim. Cosmochim. Acta, 47, 953-958.

Silver, L.A. (1988): Water in silicate glasses, Ph.D. Thesis (California Inst. Tech., Pasadena, CA).

Silver, L.A. and E. StolPER (1985): A thermodynamic model for hydrous silicate melts, J. Geol., 93, 161-177.

Silver, L.A., P.D. IHINGER and E. STOLPER (1990): The influence of bulk composition on the speciation of water in silicate glasses, Contrib. Mineral. Petrol., 104, 142162.

STOLPER, E. (1982): Water in silicate glasses: an infrared spectroscopic study, Contrib. Mineral. Petrol., 81, 1-17.

StolPer, E., G. Fine, T. Johnson and S. Newman (1987): Solubility of carbon dioxide in albitic melt, Am. Mineral., 72, 1071-1085.

TAmic, N., H. Behrens and F. Holtz (2001): The solubility of $\mathrm{H}_{2} \mathrm{O}$ and $\mathrm{CO}_{2}$ in rhyolitic melts in equilibrium with a mixed $\mathrm{CO}_{2}-\mathrm{H}_{2} \mathrm{O}$ fluid phase, Chem. Geol., 174, 333-347.

Thibault, Y. and J.R. Holloway (1994): Solubility of $\mathrm{CO}_{2}$ in a Ca-rich leucitite: effects of pressure, temperature and oxygen fugacity, Contrib. Mineral. Petrol., 116, 216-224. 